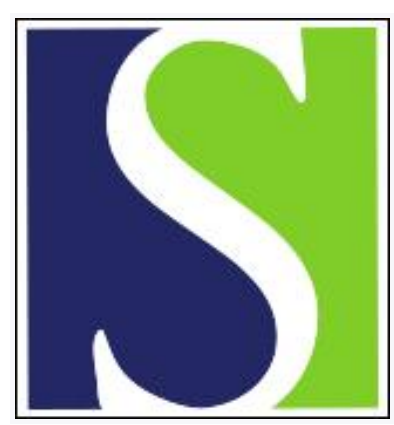

Scand J Work Environ Health 1979;5(3):188-194

https://doi.org/10.5271/sjweh.3092

Issue date: Sep 1979

Vanadium in the blood and urine of workers in a ferroalloy plant

by Gylseth B, Leira HI, Steinnes E, Thomassen Y

Affiliation: Institute of Occupational Health, PO Box 8149 DEP, Oslo 1, Norway.

Key terms: blood; exposure; ferroalloy plant; urine; vanadium; worker

This article in PubMed: www.ncbi.nlm.nih.gov/pubmed/20120566 


\title{
Vanadium in the blood and urine of workers in a ferroalloy plant
}

\author{
by BJØRN GYLSETH, M.Sc., ${ }^{1}$ HÅKON L. LEIRA, M.D., ${ }^{1}$ EILIV STEINNES, Ph.D., ${ }^{2}$ \\ and YNGVAR THOMASSEN, M.Sc. ${ }^{1}$
}

\begin{abstract}
GYLSETH, B., LEIRA, H., STEINNES, E. and THOMASSEN, Y. Vanadium in the blood and urine of workers in a ferroalloy plant. Scand. j. work environ. \& health 5 (1979) 188-194. The concentration of vanadium in the blood and urine of both nonexposed and occupationally exposed workers have been determined by neutron activation analysis. A comparison of the exposure data and the corresponding blood and urine values shows that the urine vanadium concentration adjusted for creatinine concentration is the most reliable exposure indicator. The normal levels of vanadium in blood are less than $20 \mathrm{nmol} / 1$. The corresponding urine values are less than $3.5 \mathrm{nmol} / \mathrm{mmol}$ of creatinine.
\end{abstract}

Key words: blood, exposure, urine, vanadium.

Vanadium compounds were recognized as an industrial hazard more than half a century ago (9). The discovery of high concentrations of vanadium in the fly ash from the combustion of petroleum products and coal has further increased the interest in the toxicity of vanadium compounds.

Vanadium metal is mostly used in steel alloys. Vanadium for this purpose is produced as ferrovanadium by thermoelectric reduction in arc furnaces. Furthermore, vanadium is frequently used as a catalyst.

In plants producing ferrovanadium, exposure to different vanadium compounds

\footnotetext{
1 Institute of Occupational Health, Oslo, Norway.

2 Institutt for atomenergi, Kjeller, Norway.
}

Reprint requests to: Mr. Bjørn Gylseth, Institute of Occupational Health, P.O.B. 8149 DEP, Oslo 1, Norway. occurs. The threshold limit values $(2,10)$ established for vanadium compounds seem to be based on short-term effects. To our knowledge, no long-term effects due to vanadium exposure have been reported. The health hazards of human exposure to vanadium compounds include upper airway irritation and possible sensitization followed by asthma and eczema. A green discoloration of the tongue and a metal taste are typical signs of exposure. Most of these effects have been reported after exposure to vanadium pentoxide $\left(\mathrm{V}_{2} \mathrm{O}_{5}\right)$ $(5,13,14)$. Zenz and Berg (16) reported marked upper airway irritation and cough following exposures to $0.2 \mathrm{mg}$ of $\mathrm{V}_{2} \mathrm{O}_{5}$ $\mathrm{m}^{-3}$. No systemic complaints were observed.

The only information available concerning ferrovanadium exposure was published by Roshchin (11). Through both animal and human studies he demonstrated that $\mathrm{V}_{2} \mathrm{O}_{5}$ is more toxic than ferro- 
vanadium, and based on these results a threshold limit value of $1 \mathrm{mg}$ of ferrovanadium $\cdot \mathrm{m}^{-3}$ has been recommended by the American Conference of Governmental Industrial Hygienists.

Vanadium has recently been demonstrated to be an "essential" trace element (4) that is mainly excreted via urine and feces. Its concentration in the urine of occupationally nonexposed persons is very low, and due to improving analytical procedures the "normal" urinary vanadium values have been decreasing in the last few years. Neutron activation analysis (17) seems to be the most reliable method for the analysis of vanadium at this concentration level. Several authors $(6,7,8,9,16)$ have determined the vanadium concentration in biological samples and have tried to establish a relationship between vanadium exposure and excretion. The most recent results were reported by Sabbioni et al. (12) and Cornelis et al. (3).

The purpose of the present study was to evaluate whether vanadium concentrations in blood $(\mathrm{B}-\mathrm{V})$ and urine $(\mathrm{U}-\mathrm{V})$ are suitable indicators for occupational vanadium exposure. The study was designed to examine whether variations in vanadium dust exposure produce detectable changes in the $\mathrm{U}-\mathrm{V}$ and $\mathrm{B}-\mathrm{V}$ values during a workday or a workweek and whether a correlation exists between the two parameters.

\section{FERROVANADIUM PRODUCTION}

The production of pig iron at the plant concerned started in 1927. In 1956 the production of a refined iron product called "vantit" was initiated. Blowing oxygen through liquid iron causes the vanadium contaminants in the iron to form stable oxides which can be removed as slag. The slag from this process contains 12-13\% vanadium.

After the removal of iron by magnetic separation, the vanadium slag is used as a raw material for ferrovanadium production. The slag is melted in a three-phase electrofurnace by the addition of calcium carbonate and ferrosilicon. After reduction and separation the final product contains $50 \%$ vanadium, $7 \%$ silicon, $38 \%$ iron, and $2 \%$ manganese.

The workers are exposed to slag dust containing mainly $\mathrm{V}_{2} \mathrm{O}_{5}$; other oxides may, however, be present $\left(\mathrm{VO}_{2}, \mathrm{~V}_{2} \mathrm{O}_{3}\right)$. During the reduction process the potmen are exposed to a mixture of metal and oxide fumes of iron and vanadium. The crushing and packing men are exposed to ferrovanadium dust.

\section{METHODS}

Seventeen workers participated in the investigation. In order to look for differences between persons with little or no exposure and those with moderate to high exposure, we divided the men into the following two groups:

A. 6 persons working on the pig iron furnace - none to low exposure,

B. 11 persons working in the slag production, on the ferrovanadium furnace and in the crushing/packing department moderate to high exposure.

The daily vanadium exposure of the persons in group B was recorded with personal sampling devices on four successive days (Monday-Thursday). Blood and urine samples were collected from both groups before and after the workshift the first day and after the workshift on the fourth day.

\section{Dust sampling}

The dust samples were collected on 37$\mathrm{mm}, 0.8-\mu \mathrm{m}$ Millipore membrane filters with Casella personal air samplers using an adjusted flow of approximately $21 \cdot \min ^{-1}$. The filter monitors were mounted in the breathing zone of the workers.

The filter was changed every day. Before use, the filters were desiccated for 24 $\mathrm{h}$ and weighed with an accuracy of \pm 0.1 mg. The same weighing procedure was employed after the sampling. 


\section{Dust analysis}

The filter samples were digested in Teflon autoclaves with a $1: 1$ mixture of aqua regia and hydrofluoric acid.

After digestion of the samples at $150^{\circ} \mathrm{C}$ for $30 \mathrm{~min}$, boric acid was added and heated for $15 \mathrm{~min}$ at $120^{\circ} \mathrm{C}$. The solutions were analyzed by electrothermal atomic absorption spectrometry with a Perkin-Elmer model 300 AAS equipped with a deuterium background corrector, an HGA-76 graphite furnace, a model AS-1 auto sampling system, and a model 56 recorder.

Samples of $20 \mu \mathrm{l}$ were dried at $100^{\circ} \mathrm{C}$, ashed at $1,600^{\circ} \mathrm{C}$, and atomized at $2,700^{\circ} \mathrm{C}$. The $318 \mathrm{~nm}$ vanadium resonance line was used. It was shown that standardization against pure aqueous vanadium standards using reference ferrovanadium samples gave accurate results.

\section{Biological sampling}

The urine samples were collected in acidwashed $100-\mathrm{ml}$ polyethylene bottles. The blood samples were collected in preevacuated, heparinized $10-\mathrm{ml}$ glass tubes. After the sampling, the bottles and tubes were stored at $-21^{\circ} \mathrm{C}$.

\section{Blood and urine analysis}

The vanadium concentration in the blood and urine samples was determined according to a neutron activation method described in detail elsewhere (1). Two-milliliter samples were pipetted into polyethylene tubes which were heat-sealed. Twomilliliter aliquots of an aqueous vanadium standard solution were placed in the same kind of vial. Each sample or standard was

Table 1. Mean vanadium concentration in blood (nmol/1).

\begin{tabular}{|c|c|c|c|c|c|c|}
\hline Exposure level & Mean & Range & $\begin{array}{l}\text { Statistically } \\
\text { significant } \\
\text { difference } \\
(p<0.05)\end{array}$ & $\begin{array}{l}\text { Mean } \\
\text { (total) }\end{array}$ & $\begin{array}{l}\text { Confidence } \\
\text { limits } \\
(\mathrm{p}<0.05)\end{array}$ & $\begin{array}{c}\text { Statistically } \\
\text { significant } \\
\text { difference } \\
(p<0.05)\end{array}$ \\
\hline \multicolumn{7}{|l|}{ None to low } \\
\hline $\begin{array}{l}\text { Monday morning (I) } \\
\text { Monday afternoon (II) } \\
\text { Thursday afternoon (III) }\end{array}$ & $\begin{array}{l}22.8 \\
18.7 \\
22.4\end{array}$ & $\begin{array}{r}8-54 \\
10-36 \\
10-48\end{array}$ & $\begin{array}{cc}\text { I-II } & (-) \\
\text { II-III } & (-) \\
\text { III-I } & (-)\end{array}$ & 20.2 & $15.9-25.9$ & \multirow[t]{3}{*}{$(+)$} \\
\hline \multicolumn{6}{|l|}{ Moderate to high } & \\
\hline $\begin{array}{l}\text { Monday morning (I) } \\
\text { Monday afternoon (II) } \\
\text { Thursday afternoon (III) }\end{array}$ & $\begin{array}{l}36.5 \\
38.5 \\
30.4\end{array}$ & $\begin{array}{l}12-74 \\
16-66 \\
12-58\end{array}$ & $\begin{array}{cl}\text { I-II } & (-) \\
\text { II-III } & (-) \\
\text { III-I } & (-)\end{array}$ & 35.7 & $29.8-43.0$ & \\
\hline
\end{tabular}

Table 2. Mean vanadium concentration in urine adjusted for creatinine excretion $(\mu \mathrm{mol} \mathrm{V} / \mathrm{mmol}$ creatinine $\times 10^{-2}$ ).

\begin{tabular}{|c|c|c|c|c|c|c|}
\hline Exposure level & Mean & Range & $\begin{array}{l}\text { Statistically } \\
\text { significant } \\
\text { difference } \\
(\mathrm{p}<0.05)\end{array}$ & $\begin{array}{l}\text { Mean } \\
\text { (total) }\end{array}$ & $\begin{array}{l}\text { Confidence } \\
\text { Iimits } \\
(p<0.05)\end{array}$ & $\begin{array}{l}\text { Statistically } \\
\text { significant } \\
\text { difference } \\
(\mathrm{p}<0.05)\end{array}$ \\
\hline \multicolumn{7}{|l|}{ None to low } \\
\hline $\begin{array}{l}\text { Monday morning (I) } \\
\text { Monday afternoon (II) } \\
\text { Thursday afternoon (III) }\end{array}$ & $\begin{array}{l}0.39 \\
0.36 \\
0.34\end{array}$ & $\begin{array}{l}0.13-0.58 \\
0.14-0.55 \\
0.10-0.69\end{array}$ & $\underset{\mathrm{III}-\mathrm{III}}{\mathrm{I}-\mathrm{II}} \stackrel{(-)}{(-)}$ & 0.36 & $0.27-0.48$ & \multirow[t]{3}{*}{$(+)$} \\
\hline \multicolumn{6}{|l|}{ Moderate to high } & \\
\hline $\begin{array}{l}\text { Monday morning (I) } \\
\text { Monday afternoon (II) } \\
\text { Thursday afternoon (III) }\end{array}$ & $\begin{array}{l}1.21 \\
1.54 \\
1.82\end{array}$ & $\begin{array}{l}0.67-1.60 \\
0.68-3.60 \\
0.44-2.42\end{array}$ & $\underset{I I I-I}{I I I} \stackrel{(-)}{(-)}$ & 1.52 & $1.23-1.87$ & \\
\hline
\end{tabular}


irradiated for $5 \mathrm{~min}$ in a JEEP-II reactor (Kjeller, Norway) at a thermal flux of $1.5 \times 10^{13} \mathrm{n} \mathrm{cm}^{-2} \mathrm{~s}^{-1}$. After the irradiation the sample was digested with $\mathrm{HNO}_{3} / \mathrm{H}_{2} \mathrm{SO}_{4}$ in a $250-\mathrm{ml}$ beaker in the presence of 2.5 $\mathrm{mg}$ of a vanadium $(\mathrm{V})$ carrier and a known amount of ${ }^{48 \mathrm{~V}}$ tracer with the use of an electrothermal burner. Then the beaker was carefully cooled with water, $10 \mathrm{ml}$ of $8 \mathrm{M} \mathrm{HCl}$ were added, and the solution was extracted with $25 \mathrm{ml}$ of $50 \%$ (v/v) tributylphosphate in toluene in a separator funnel. After being washed with $10 \mathrm{ml}$ of 8 $\mathrm{M} \mathrm{HCl}$, the organic phase was transferred to a $100-\mathrm{ml}$ polyethylene bottle, and the $\gamma$ activity of the separated sample was recorded with a $\mathrm{Ge}(\mathrm{Li})$ detector connected to a multichannel analyzer. The counting period was $5 \mathrm{~min}$, and it began about 8 min after the end of the irradiation. The analysis was based on the $1434 \mathrm{keV} \gamma$ ray of ${ }^{52} \mathrm{~V}\left(\mathrm{~T}^{1 / 2}=3.8 \mathrm{~min}\right)$. The chemical yield for the separation was $50-70 \%$, as measured by means of the $983 \mathrm{keV} \gamma$ ray of the ${ }^{48} \mathrm{~V}$ tracer. ${ }^{48} \mathrm{~V}$ is not produced from natural vanadium by thermal neutron activation.)

\section{RESULTS}

The mean vanadium concentration in blood and urine is given for the two groups in tables 1 and 2, respectively. With the assumption of a log-normal dis- tribution, the confidence limits at the $\mathrm{p}<0.05$ level are calculated and the statistical significance indicated (Student's ttest). One of the workers showed a significantly higher $\mathrm{U}-\mathrm{V}$ and $\mathrm{B}-\mathrm{V}$ concentration than the others. His B-V value was especially high before work on the first day. This high value may be due to the fact that this man, unlike the others, had been at work the two previous days. A high exposure often occurs at his worksite (slag separation). His values have been omitted from the following discussion, the results presented being based therefore on the value determined for the other 16 workers.

There was a statistically significant difference in the $\mathrm{B}-\mathrm{V}$ and $\mathrm{U}-\mathrm{V}$ concentrations $(p<0.001)$ between the two groups. No statistically significant difference was found between the before and after shift values on the first day or between the before shift values on the first day and after shift values on the fourth day. It was shown that for the moderate to high exposure group there was a slight increase in vanadium excretion during the period of investigation (significant at the $\mathrm{p}<0.15$ level), while the $\mathrm{B}-\mathrm{V}$ values revealed no significant alteration. A fair correlation between the $\mathrm{U}-\mathrm{V}$ and $\mathrm{B}-\mathrm{V}$ concentrations was found $(r=0.50)$. These results are plotted in log-log scale in fig. 1.

The $\mathrm{B}-\mathrm{V}$ and $\mathrm{U}-\mathrm{V}$ concentrations after the workshift on the first and the fourth day were also plotted versus the vanadium

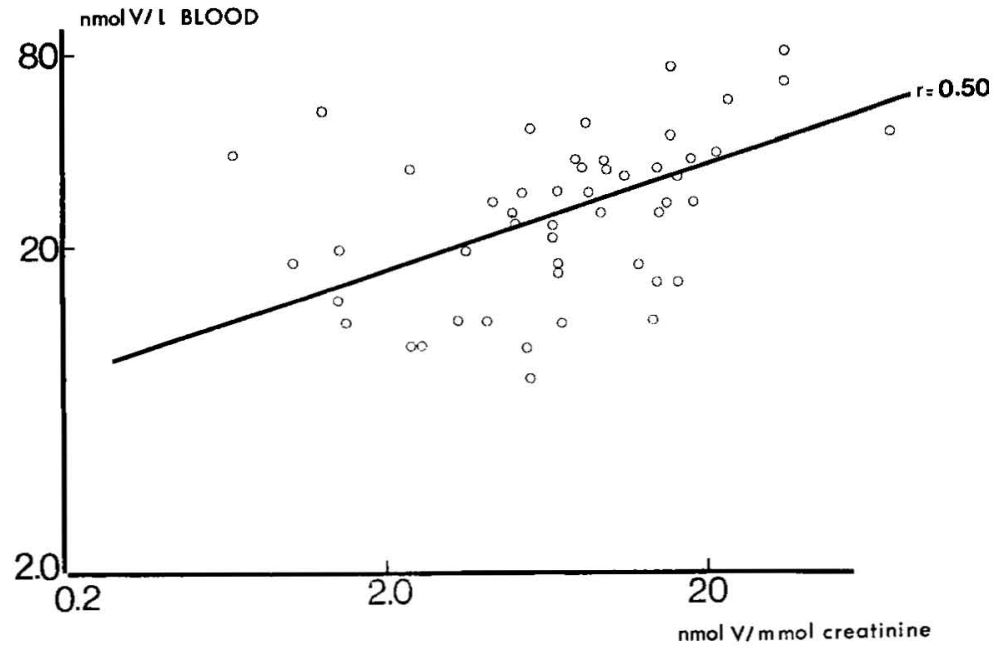

Fig. 1. Correlation between the concentration of vanadium (V) in blood and urine adjusted for creatinine excretion. 

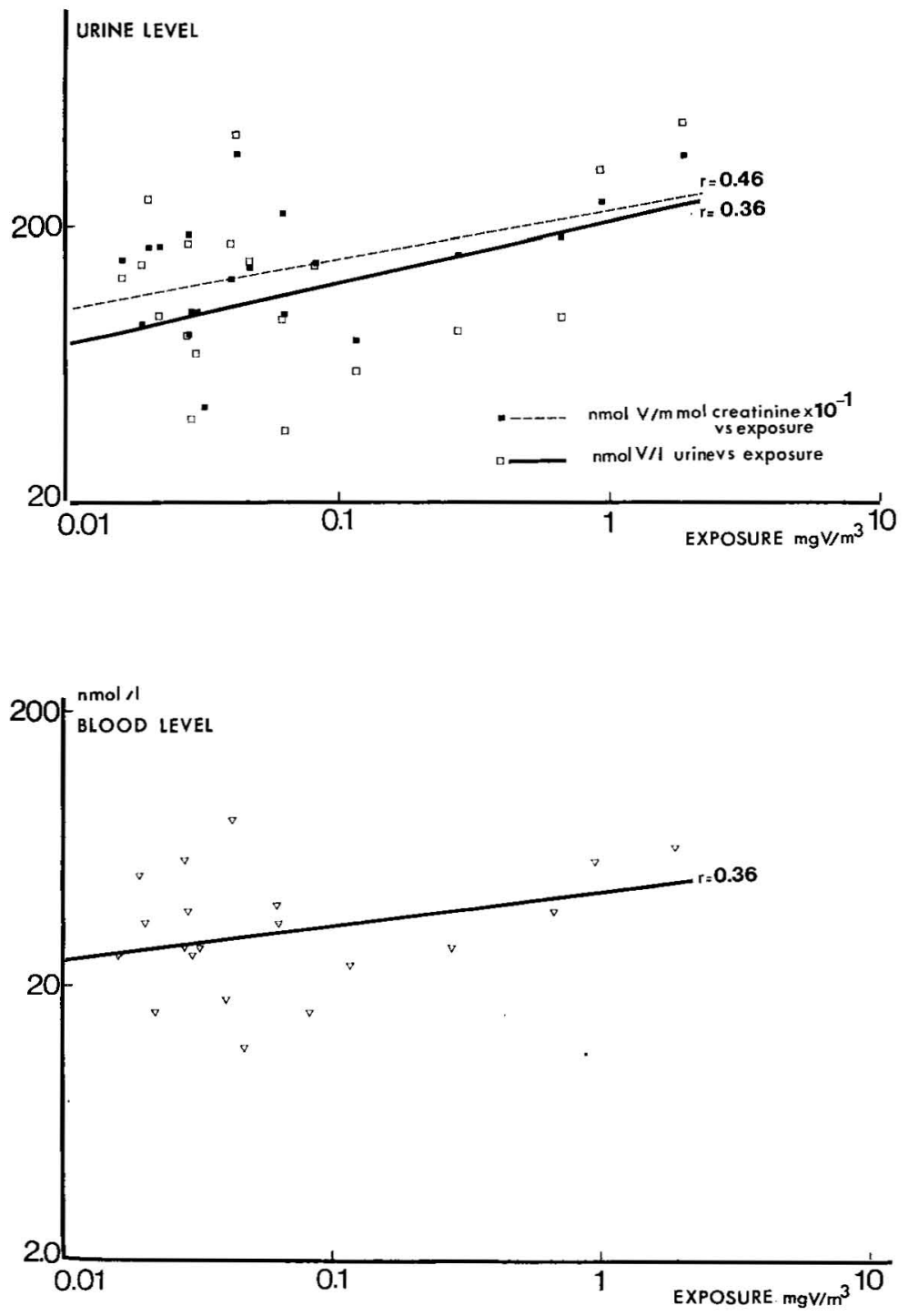

Fig. 2. Correlation between the vanadium (V) concentration in urine and the daily total vanadium exposure (-); the urinary concentration of vanadium has been adjusted for creatinine and the daily total vanadium exposure $(-\longrightarrow-$ ).
Fig. 3. Correlation between the vanadium (V) concentration in blood and the daily total vanadium exposure. exposure the same days, respectively. These results are shown in fig. 2 and 3 . In fig. 2 it can be seen that the vanadium excretion adjusted to the urinary creatinine concentration shows a slightly higher correlation with vanadium exposure than does the $U-V$ value ( $r=0.46$ vs. $r=0.36$ ).

In a separate experiment to test the precision of the analytical method, six aliquots of a pooled sample of blood from a nonexposed person ("normal blood") were analyzed, and the concentration was found to be $15.4 \pm 1.8 \mathrm{nmol} / 1$.

\section{DISCUSSION}

A comparison of the exposure and the concentration of vanadium in blood and urine demonstrates that the urinary concentration adjusted for creatinine concentration is the most reliable exposure indicator. At the exposure levels encountered in this study, the $B-V$ and $U-V$ values for a single worker give no clear information about the exposure level. However, on a group basis, B-V and U-V analysis can be used to reveal exposure, and under certain 
conditions the U-V analysis may give an indication of the exposure level. However, the differences are small and the method difficult and expensive, so for routine control other criteria should be sought for the control of vanadium dust exposure of this kind.

It is evident from the present investigation that neutron activation analysis, as applied in this work, is adequately sensitive for the determination of normal vanadium levels in urine and presumably also in blood. The precision is $\pm 10 \%$ or better for vanadium levels exceeding 20 $\mathrm{nmol} / \mathrm{l}$. The possibility of blank contribution, however, cannot be excluded. An analysis of distilled water stored in the same kind of glass tubes as those used for the collection of the blood samples showed values on the order of 5-10 nmol V/1. Furthermore, contamination from steel syringe tips could be significant. This possibility does not affect the preceding discussion of group differences, but it may lead to considerable relative error, especially in the case of "normal" blood.

In a recent investigation by Sabbioni et al. (12) the vanadium concentration in the blood of nonexposed persons from Italy was found to be within the range of $16-$ $140 \mathrm{nmol} / 1$, with a mean value of $72 \mathrm{nmol} /$ 1 , which is significantly higher than the "normal" level indication in the present study. About $90 \%$ of the blood vanadium was found to be in the plasma, and it was predominantly associated with transferrin. Cornelis et al. (3), on the other hand, reported values of $0.3-5.2 \mathrm{nmol} / \mathrm{l}$ for 17 human sera from Belgium, and these concentrations are appreciably lower than the present data. An analysis of an additional number of samples showed results confirming this concentration level (R. Cornelis, personal communication). The reason for the observed differences is not known at present. Geographic variations associated with nutritional habits might account for some difference in B-V values, but hardly as much as a factor of 50 between different areas of Central Europe. What seems to be apparent, however, is that the $\mathrm{B}-\mathrm{V}$ concentration, in the absence of significant environmental exposure, is much lower than what has previously been assumed.

\section{ACKNOWLEDGMENT}

The authors wish to thank Elkem-Spigerverket $\mathrm{A} / \mathrm{S}$, Bremanger Smelteverk, for their kind assistance.

\section{REFERENCES}

1. ALlEN, R. O. and STEINNES, E. Determination of vanadium in biological materials by radiochemical neutron activation analysis. Anal. chem. 50 (1978) 1553-1555.

2. AMERICAN CONFERENCE OF GOVERNMENTAL INDUSTRIAL HYGIENISTS. Threshold limit values for chemical substances and physical agents in the workroom environment with intended changes for 1978. Cincinnati, OH 1978. $94 \mathrm{p}$.

3. CORNELIS, R., MEES, L., HOSTE, J., RYCKEBUSCH, J., VERSIECK, J. and BARBIER, F. Neutron activation analysis of vanadium in human liver and serum. In: INTERNATIONAL ATOMIC ENERGY AGENCY, Nuclear activation techniques in the life sciences. Vienna. (in press)

4. HOPKINS, L. L. JR. and MOHR, H. E. The biological essentiality of vanadium. In W. MERZ and W. E. CORNATZER (eds.), Newer trace elements in nutrition. Marcel Decker, New York, NY 1971, pp. 159-213.

5. HUDSON, T. G. F. Vanadium: Toxicology and biological significance (monograph no. 36, Elsevier monograph series). Elsevier Scientific Publishing Co. Inc., New York, NY $1964.140 \mathrm{p}$.

6. HULCHER, F. E. Spectrometric determination of vanadium in biological material. Anal. chem. 32 (1960) 1183-1185.

7. JARACZEWSKA, W. and JAKUBOWSKI, M. Preliminary evaluation of exposure to vanadium dust in chemical industry. Presented at the XIV International Congress of Occupational Health, Madrid, 1963.

8. LEWIS, C. E. The biological effects of vanadium: II. The signs and symptoms of occupational vanadium exposure. Arch. ind. health 19 (1959) 497-503.

9. MEDICAL AND BIOLOGICAL EFFECTS OF ENVIRONMENTAL POLLUTANTS COMMITTEE ON BIOLOGICAL EFFECTS OF ATMOSPHERIC POLLUTANTS. Vanadium. National Academy of Sciences, Washington, DC 1974.

10. NATIONAL INSTITUTE FOR OCCUPATIONAL SAFETY AND HEALTH. Criteria for a recommended standard. . Occupational exposure to vanadium (NIOSH publication no. 77-222). U.S. Department of Health, Education and Welfare, Cincinnati, OH 1977. $142 \mathrm{p}$.

11. ROSHCHIN, I. V. Toxicology of vanadium compounds used in modern industry. Gig. sanit. 32 (1967) 26-32.

12. SABBIONI, E., MARAFANTE, E., PIETRA, R., GOETZ, L. GIARDI, F. and ORVINI, E. 
The association of $\mathrm{V}$ with the iron transport system in human blood as determined by gel filtration and neutron activation analysis. In: INTERNATIONAL ATOMIC ENERGY AGENCY, Nuclear activation techniques in the life sciences. Vienna. (in press)

13. SJOBERG, S. G. Vanadium pentoxide dust: A clinical and experimental investigation on its effect after inhalation. Acta med. scand. 138 (1950): suppl. 238, 188 p.

14. SJÖBERG, S. G. Vanadium dust, chronic bronchitis and possible risk of emphysema: A follow-up investigation of workers at a vanadium factory. Acta med. scand. 154 (1956) $381-386$.

15. VALBERG, L. S. and HOLT, J. M. Detection of vanadium in normal human erythrocytes. Life sci. 3 (1964) 1263-1265.

16. ZENZ, C. and BERG, B. A. Human responses to controlled vanadium pentoxide exposure. Arch. environ. health 14 (1967) $709-712$.

17. ZOLLER, W. H. and GORDON, G. E. Instrumental neutron activation analysis of atmospheric pollutants utilizing $\mathrm{Ge}$ (Li) X-ray detectors. Anal. chem. 42 (1970) 257265.

Received for publication: 2 February 1979 